\title{
Recalling Student Leaders: Analysing the Advancement of Constitutionalism, Democracy and Transparency
}

\author{
Dr. Mwanawina llyayambwa \\ Lecturer (International Law), North West University, Vaal Triangle Campus, \\ School for Basic Sciences, PO Box 1174, Vanderbijlpark, South Africa, 1900 \\ Email: mwanawinai@gmail.com or 18012264@nwu.ac.za
}

\section{Doi:10.5901/mjss.2014.v5n20p2164}

\begin{abstract}
Constitutionalism is the idea, often associated with the political theories, that an authority wielding public power or purporting to represent the interest of the governed can and should be legally limited in its powers, and that its authority or legitimacy depends on its observing these limitations. Student Representative Councils (SRC's) have become an integral part of higher education governance. Despite this, very little attention and research has been aimed at scrutinizing the legal infrastructure which is grundnorm of these formations. This paper focuses on the recall clause which has become a common provision in the constitutions establishing a SRC and commonly used to remove an office bearer from the SRC. The question to be addressed by this paper is to determine whether or not the usage of the recall clause is in line with South African Constitutional values that embody democracy, accountability and transparency. The work relies on various political and constitutional theories to advance its arguments and concludes that in view of the democratic principles enshrined in the Constitution of the Republic of South Africa, any exercise to recall a student leader by a deploying structure without the support or adoption by the majority of members in a legitimate student parliamentary structure (or student mass meeting) does not espouse that values of transparency.
\end{abstract}

Keywords: Constitutionalism, Higher Education, Student Representative Council

\section{Introduction}

Constitutionalism is the idea, often associated with the political theories, that an authority wielding public power or purporting to represent the interest of the governed can and should be legally limited in its powers, and that its authority or legitimacy depends on its observing these limitations. ${ }^{1}$ The evolution of student governance in higher education institutions within South African society has played a significant role in shaping the democracy that the country experiences today. Student political formations in learning institutions have contributed immensely to the resistance of apartheid practices ultimately leading to the transition of a democratic South Africa. Overtime, the legislative framework of South African Higher Education has changed to grant formal recognition to student bodies, acknowledging them as legitimate stakeholders in the governance of institutions. This has been a much welcome position as compared to the antagonistic relationship that the former regime had with student formations.

Despite this shift in mind-set, very little attention and research has been aimed at scrutinizing the legal infrastructure which is grundnorm of these student governing formations. The grundnorm here referring to the founding documents or Constitutions that regulate the exercise of powers conferred upon such a Student Representative Council (SRC). This paper will not analyse the whole body of SRC Constitutions but focus on a particular clause that seems to be common in most SRC Constitutions. The "recall clause" has been welcomed by student leaders as a failsafe switch of last resort against a student government or an office bearer that has lost the confidence of the masses. This clause grants the political party that successfully contested elections the ability to remove and replace a member of the SRC with a different person of their choice. The question to be addressed by this paper is to determine whether or not the usage of the recall clause is in line with South African constitutional values that embody openness, democracy and accountability. The work will rely on various political and constitutional theories to advance its arguments.

\footnotetext{
1 See Vile, M. J. C. (1967). Constitutionalism and the Separation of Powers, p. 13. Oxford: Clarendon Press.
} 


\title{
2. Background to South African Higher Education
}

The legislative framework of South African higher education is embodied in the Higher Education Act $^{2}$ which establishes the legal basis of a single, national higher education system on the basis of the rights and freedoms of the South African Constitution. ${ }^{3}$ The Higher Education Act replaces the 1995 Universities Act, ${ }^{4}$ the 1988 Tertiary Education Act, ${ }^{5}$ and the 1993 Technikons Act. ${ }^{6}$

The Higher Education Act establishes that every public higher education institution established, deemed to have been established or declared as a public higher education is a juristic person. ${ }^{7}$ A question may then be posed to the obligations of juristic persons towards the values embedded in our democracy. The South African Constitution articulates that:

This Constitution is the supreme law of the Republic; law or conduct inconsistent with it is invalid, and the obligations imposed by it must be fulfilled. 8

A provision of the Bill of Rights binds a natural or a juristic person if, and to the extent that, it is applicable, taking into account the nature of the right and the nature of any duty imposed by the right. ${ }^{9}$

This then has the implication that all the decision making process as well as the actions of higher education institutions have to adhere and promote the values enshrined in the Constitution. It is worth noting further that the despite the Higher Education Act using the phrase 'public higher education institutions' in section 20(4), private education institutions are not immune from the judicial review against the values of the Constitution. In Klein v Dainfern College and Another, ${ }^{10} \mathrm{a}$ dispute pertaining to disciplinary hearings and procedural fairness arose in a private learning institution. The Court in illustrating that procedural fairness as a value stemming from the Constitution is applicable to even private bodies opined that;

\begin{abstract}
No rational reason exists to exclude individuals from the protection of judicial review in the case of coercive actions by private tribunals not exercising any public power. To my mind the Constitution makes no pronouncements in respect of this branch of private administrative law. Thus, continuing to apply the principles of natural justice to the coercive actions of private tribunals exercising no public powers will in no way be abhorrent to the spirit and purport of the Constitution.11
\end{abstract}

The above extract illustrates the wide reach that the values of the Constitution have on higher education processes. In another case, Baloro v University of Bophuthatswana, ${ }^{12}$ the Bophuthatswana Supreme Court ruled in favour of the applicants who sought relief against a University moratorium on promotion of non-South African academic staff whilst South African staff continued to be promoted. The court relied on the horizontal application of the Bill of rights as a means of constraining the abuse of power. The emphasis illustrated in these cases is that no matter how remote or isolated a process is from the traditional organs of state, all processes in South Africa have to adhere to the values of the Constitution, including decisions by student governing bodies.

The Higher Education Act gives a broad framework on how institutional statutes are to be structured. It provides that University Councils are the highest decision-making bodies of public institutions. They are responsible for the good order and governance of institutions and for their mission, financial policy, performance, quality and reputation. ${ }^{13}$ Other bodies and offices established by the Act include the senate; principal; vice-principal; students' representative council; institutional forum; and any other such other structures and offices as may be determined by the institutional statute. ${ }^{14}$ The Act therefore leaves much scope for individual institutions with regards to interpretation and implementation.

For the purposes of this paper, it is worth highlighting the specific sections that ensure that students, as stakeholders are represented in the decision making structures of the University.

- Section 27(4)(f), The Council of a public higher education institution must consist of (amongst other stakeholders), students of the public higher education institution elected by the student representative council.

\footnotetext{
2 HE Act No 101 of 1997.

${ }^{3}$ Act 108 of 1996.

${ }^{4}$ Act No. 61 of 1955 .

${ }^{5}$ Act No. 66 of 1988

${ }^{6}$ Act No. 125 of 1993.

${ }^{7} \mathrm{Sec} 20$ (4).

${ }^{8} \mathrm{Sec} 2$.

${ }^{9} \operatorname{Sec} 8(2)$.

102006 (3) SA 73 (T).

11 at para 24.

121995 (4) SA 197.

13 White Paper on Higher Education, General Notice 1196 of 1997, Principle 3.34

${ }_{14} \operatorname{Sec} 26(2)(a)-(g)$.
} 
The council must also provide for a suitable structure to advise on the policy for student support services within a public higher education institution after consultation with the student representative council;

- Section 28(2)(f), The senate of a public higher education institution must consist of (amongst other stakeholders), the student representative council;

- Section 31(2)(f), The institutional forum of a public higher education institution must consist of representatives of (amongst other stakeholders), the students;

The rationale behind this form of arrangements can be found in history of South Africa as a state. The resistance against undemocratic forms of governance against the Apartheid regime was not only fought by political and human rights activists. Students (both at tertiary, secondary and primary level) had a good deal to do with garnering the support for the defiance campaigns that attracted international awareness to the injustices of the apartheid regime. The conditions at black universities also contributed to the politicisation of black students. Their location in the rural areas, far from urban complexes, the state's emphasis on ethnically restricting the student body, the predominantly Afrikaner staff that was politically conservative, the close association of the residences, the brutal violence of the police against peaceful protest, and the emergence of a culture of political resistance from the early 1970's associated with the black consciousness movement, all contributed in some way to student resistance. ${ }^{15}$ These circumstances then brought to light the need for constant organised student structures that opposed racist regimes.

Taking heed of the history, the White paper on Higher Education was initiated with the establishment of the National Commission on Higher Education (NCHE) in February 1995 by President Mandela. ${ }^{16}$ The bedrock of the White paper was to provide a basis upon which the practices of higher education in South Africa would face targeted reforms in order to ensure that it reflects the democratic changes occurring in the rest of the country. The paper is still used argued that it is important to transform and democratise the governance structures of higher education. New structures should provide for co-operative decision-making between separate but functionally interdependent stakeholders who recognise their different identities, interests and freedoms, while pursuing the common goal of a co-ordinated and participative polity and civil society. ${ }^{17}$ Amongst these stake holders are students and civil society and as such the Higher Education Act includes student representatives in decision making structures. It is also notable that the White paper recommended that to sustain public confidence, councils should include a majority of at least 60 per cent of members external to the institution. ${ }^{18}$

The White paper further echoed the principle of democracy; that the principle of democratisation requires that governance of the system of higher education and of individual institutions should be democratic, representative and participatory and characterised by mutual respect, tolerance and the maintenance of a well-ordered and peaceful community life. Structures and procedures should ensure that those affected by decisions have a say in making them, either directly or through elected representatives. It requires that decision-making processes at the systemic, institutional and departmental levels are transparent, and that those taking and implementing decisions are accountable for the manner in which they perform their duties and use resources. ${ }^{19} \mathrm{It}$ is then befitting that the students, as major stakeholders in the civil society are involved in the decision making structures that have a direct or indirect impact in their higher education experience.

Having traversed the environment within which students function, this paper will now draw attention to the Sec 35 of the Higher Education Act which provides for the Students' Representative Council. It provides that;

The establishment and composition, manner of election, term of office, functions and privileges of the students' representative council of a public higher education institution must be determined by the institutional statute and the institutional rules.

This provision gives the various institutions the flexibility to prescribe how the SRC is established. An institution may opt for a federal structure if it has two or more SRCs co-existing at different satellite campuses. A unitary model is where there is only one SRC representing students of the institution. This can take place in a single-campus institution or in a multi-campus institution with the necessary adjustments. A hybrid form of student governance is one in which there are elements of both federal and unitary structures. For instance, the North West University Statute ${ }^{20}$ establishes an Institutional SRC comprising of members from the Campus SRC's. Each Campus (Mafikeng, Potchefstroom and Vaal Campus) has its own SRC and has the exclusive jurisdiction together with bodies on that Campus to regulate student

\footnotetext{
${ }^{15}$ Reddy, T. (2004). Higher education and social transformation: South Africa case study, pg 26

${ }^{16}$ White Paper, Ibid note 13.

17 White Paper, Ibid note 13, Goal 1.28

${ }^{18}$ White Paper, Ibid note 13 , at 3.34

19 White Paper, Ibid note 13, Principle 1.19

20 Government Notice No. 795 of 2005.
} 
matters without interference from the ISRC. ${ }^{21}$

All SRC bodies in South Africa have a set of rules, commonly known as the Constitution. The constitution can also be defined as a bundle of basic principles upon which the legal order, bureaucracy and operationalization of an entity is documented. Though not all Constitutions contain this, there exists what has commonly become known as the 'recall clause'. This is a provision that allows the student body or the party / organisation that successfully contested for a position to remove and replace such an office bearer with another person of their choice.

\section{SRC Constitutions and Recall Clauses}

In order to properly contextualise what a recall clause is, the following extracts have been obtained from randomly selected Constitutions within South African Higher Education institutions.

Section 4.1.3(a) of the Walter Sisulu University SRC Constitution provides that:

(a) Deploying student political structure shall have the right to replace one or more of their representatives, provided that such replacements may not be made within the first three months of the term of office of the ISRC/CSRC;22

Section 10.1.1(g) of the University of South Africa SRC Constitution provides that the membership of an SRC bearer is terminated if such a member is:

recalled by the student organisation which he/she represent subsequent to an organisation having provided the university with a declaration that a recall complies with its own internal procedures. ${ }^{23}$

Section 9.3 of the University of Kwazulu-Natal SRC Constitution provides that:

Student organizations opting to exercise the right of replacement are required to inform the CSRC or a LSRC, and the student governance office, of its decisions in writing, providing sound reasons why the recall is being made, and providing a timeframe for the replacement. 24

Section 25.1 of the Nelson Mandela Metropolitan University SRC Constitution articulates that:

A student organisation that has won the right to deploy one or more of its members to one or more of the portfolios listed in Section 10 (2) above, may exercise the right to recall one or more of its deployee(s) from the SRC. The student organization that recalls its deployee(s) must formally notify the secretary of the SRC and the senior staff member in the Department of Student Governance \& Development thereof, stating the reason(s) for the recall and the time from which the recall will be effective. 25

The above clauses illustrate the accountability function that student leaders have to play towards the organisation that deployed them into student government. In most cases, as illustrated above, the recall clause is effected by the deploying organisation and not the student populace. These governance arrangements reflect values about the distribution and exercise of authority, responsibility and accountability. ${ }^{26}$ This has its merits and de-merits but the crux of this paper is to argue whether or not the usage of these clauses reflects values of an accountable, democratic and transparent form of governance. It is important to note that these principles are enshrined in the Constitution of the Republic of South Africa, the Higher Education Act as well as the philosophical underpinnings of the White Paper on Higher Education.

\subsection{Democracy and Public Accountability}

The origins of democracy and civic participation of governance are pillars of a true constitutional democracy. According to Rothchild, Athenian democracy is the world's oldest well documented democratic polity, and as such has served as an inspiration, and cautionary tale, for the designers of all subsequent democracies. It is inspirational because it empowered citizens to an extent that is virtually unique among systems of government that the world has known. ${ }^{27}$ The darker side of democracy, ironically, is that the majority can be wrong and can end up peddling seeds of their own destruction. The

\footnotetext{
${ }^{21}$ See Sec 29-32 of the Statute of the NWU.

22 Walter Sisulu University SRC Constitution, (2012)

${ }^{23}$ University of South Africa (UNISA) SRC Constitution, (2006) revised 2013.

24 The University of Kwazulu-Natal SRC Constitution (2006).

${ }^{25}$ Nelson Mandela Metropolitan University (NMMU) SRC Constitution, (2006) revised 2010.

${ }^{26}$ White Paper, Ibid note 13, Principle 3.2

${ }_{27}$ Rothchild, J. (2007). Introduction to Athenian Democracy of the Fifth and Fourth Centuries BCE. Wayne State University Law School Research Paper, (07-32) at pp 4.
} 
solution to this is to seek a constitutional alternative in synergy with popular governance. This is well illustrated in the case of $S$ v Makwanyane ${ }^{28}$ in which the court as resolved that;

I am, however, prepared to assume that it does and that the majority of South Africans agree that the death sentence should be imposed in extreme cases of murder. The question before us, however, is not what the majority of South Africans believe a proper sentence for murder should be. It is whether the Constitution allows the sentence...Public opinion may have some relevance to the enquiry, but in itself, it is no substitute for the duty vested in the Courts to interpret the Constitution and to uphold its provisions without fear or favour. If public opinion were to be decisive there would be no need for constitutional adjudication. 29

The above extract shows that in a democracy such as that of South Africa, a majority rules approach is not the most ideal. The national government all the way to minute structures have to be guided by a concrete set of values. ${ }^{30}$ The contention now is whether the recall clauses are in line with these values. Ancient Greek practices as well as national practices in South African may give guidance in determining this.

Greek philosophers, Rousseau and Solon have argued extensively towards the democratisation of Greece. Solon, taught that in times of political dissension it was compulsory for each citizen to form and express his judgment. Solon also introduced the idea that a man ought to have a voice in selecting those in whose rectitude and wisdom he was compelled to entrust his fortune, his family and his life. ${ }^{31}$ Rousseau proposed that in public meeting at two stage approach should always be instructive in determining whether the status quo of leadership should be maintained. He submitted the following inquiries;

The first is: "Does it please the Sovereign to preserve the present form of government?"

The second is: "Does it please the people to leave its administration in the hands of those who are actually in charge of it?"32

Recall clauses relate to an Athenian practice called "Epikheirotonia." This translated to voting by a show of hands. In this practice, at the first meeting of the Greek Assembly, there was a vote on whether public officials were performing their duties well. If the vote went against an official, he was provisionally deposed from office, and he would be tried before a jury court. If convicted, he would be removed from the position, and might be fined. ${ }^{33}$

Closely related to this were the events leading to the United States Declaration of Independence. The Declaration submitted that;

That to secure these rights, Governments are instituted among Men, deriving their just powers from the consent of the governed,...34

That whenever any Form of Government becomes destructive of these ends, it is the Right of the People to alter or to abolish it, and to institute new Government, laying its foundation on such principles and organizing its powers in such form, as to them shall seem most likely to effect their Safety and Happiness. Prudence, indeed, will dictate that Governments long established should not be changed for light and transient causes ${ }^{35}$

The practice of Epikheirotonia and the above extracts from the Declaration illustrate that one of the building blocks of democracy is to be ruled over by an authority of one's choice. On these grounds, the basis of the recall clause may be founded since SRC Officers represent a student population.

On the South African Constitutional sphere, Section 1(d) as well as Section 195(1)(a) of the South African Constitution emphasize accountability in all spheres of governance. The word 'democracy' or 'democratic' are mentioned 30 times or more within the Constitution. Section 89 (1) provides that The National Assembly, by a resolution adopted with a supporting vote of at least two-thirds of its members, may remove the President from office only on the grounds of: (a) a serious violation of the Constitution or the law; (b) serious misconduct; or (c) inability to perform the functions of office. Section 102 (2) provides that If the National Assembly, by a vote supported by a majority of its members, passes a

\footnotetext{
281995 (3) SA 391

${ }^{29}$ at para $87-89$.

30 The Constitution of the Republic of South Africa makes reference to values such as democracy, accountability, rule of law etc...

${ }^{31}$ Mbao, M. L. M. (2010). Constitutionalism and the rule of law in the third millennium, pp7.

${ }^{32}$ Rousseau, J. J., \& Singh, E. B. N. (Eds.). (2006). Of the Social Contract, Or, Principles of Political Right. Global Vision Publishing Ho.

${ }^{33}$ Rothchild, J., Ibid note 27, pp 35.

${ }^{34}$ Extract from the 1776 United States Declaration of Independence.

${ }^{35}$ Extract from the 1776 United States Declaration of Independence.
} 
motion of no confidence in the President, the President and the other members of the Cabinet and any Deputy Ministers must resign.

The provisions as well as the cited Greek practices illustrate that regardless of the timezone, democratic practices have always been based on social relations and confidence in the government. It is thus submitted that the current practices by student governance structures in South Africa to remove one or more office bearers is well grounded within the fibre of democracy and national constitutional practices within the Republic.

\subsection{Accountability}

The White paper envisaged that the principle of public accountability implies that institutions are answerable for their actions and decisions not only to their own governing bodies and the institutional community but also to the broader society. Firstly, it requires that institutions receiving public funds should be able to report how, and how well, money has been spent. Secondly, it requires that institutions should demonstrate the results they achieve with the resources at their disposal. Thirdly, it requires that institutions should demonstrate how they have met national policy goals and priorities. ${ }^{36}$ Student governing bodies are not excluded from these requirements. Through their Constitutions, they specify how often mass meetings are held and which officers are accountable for what aspect of the governing structure.

Accountability brings into light two role players, the actor and the forum. Bovens argued that the 'accounting' usually consists of at least three elements or stages. First of all, the actor must feel obliged to inform the forum about his conduct, by providing various sorts of data about the performance of tasks, about outcomes, or about procedures. Often, particularly in the case of failures or incidents, this also involves the provision of justifications. This then, can prompt the forum to interrogate the actor and to question the adequacy of the information or the legitimacy of the conduct. This is the debating phase hence, the close semantic connection between 'accountability' and 'answerability'. ${ }^{37}$

In terms of administrative justice, there obviously has to be a form of reaction by the forum to the submissions. This is where Boven then stresses that;

\footnotetext{
...thirdly, the forum usually passes judgement on the conduct of the actor. It may approve of an annual account, denounce a policy, or publicly condemn the behaviour of a manager or an agency. In passing a negative judgement the forum frequently imposes some sort of sanctions on the accountor. These sanctions can be highly formalized, such as fines, disciplinary measures or even penal sanctions. 38
}

It is submitted in this paper that these sanctions as observed by Boven may lead to exercise of a recall clause. The exercise of public authority by SRC members should therefore not be taken for granted. Public accountability is aimed to enhance the public confidence in government and to bridge the gap between citizens and representatives and between governed and government. ${ }^{39}$ With the necessary adjustments, these principles may also apply to student governing structures in South Africa and as such the recall clause is in line with the principle of democracy and public accountability.

\subsection{Transparency}

The question that this paper has to address next is in relation to the transparent application of the recall clauses. The clauses that have been cited in this work give the right to recall to a student political structure or organisation that had successfully contested elections. Can it be deemed to be a transparent and democratic decision when a small group of the governed is given the power of the majority of the student populace to remove a representative who not only represents the interests if the party, but represents a broader population by virtue of having been elected to office? In order to be able to answer this question, it is deserving that we look closely at the principle of transparency.

It has already been indicated in this paper that the White paper as well as the Higher Education Act requires that decision-making processes at the systemic, institutional and departmental levels should be transparent, and that those taking and implementing decisions are accountable for the manner in which they perform their duties and use resources ${ }^{40} \mathrm{It}$ is submitted that the student governing bodies are not exempt from these principles.

The White paper also submits that good governance must be based on a recognition of the existence of different interests and the inevitability of contestation among them, and must therefore create structures and encourage processes

\footnotetext{
${ }^{36}$ White Paper, Ibid note 13, Principle 1.25

${ }^{37}$ Bovens, M. (2005). Public accountability. The Oxford handbook of public management, 182-208.

${ }^{38}$ Bovens, M., Ibid note 37.

${ }^{39}$ Bovens, M., Ibid note 37.

40 White Paper, Ibid note 13, Principle 1.19.
} 
which enable differences to be negotiated in participative and transparent ways. ${ }^{41}$ Like any governing model. Student governance in South Africa has multiple stakeholders ranging from the SRC officers, political formations and clubs/ societies. It is then inevitable that there is bound to be structural conflict and contestation. It is submitted that the contestation between student governing bodies and their constituencies, societies and other sub-structures requires that the SRC manage these contestations in a manner that reflects cooperative governance. This cooperative governance can be achieved through the creation of a student parliament. Some Universities in South Africa have established a functional student parliament to complement the activities of the SRC. To mention a few, Stellenbosch University, University of Venda, University of South Africa and University of Cape Town have policies establishing a Student Parliament. ${ }^{42}$ Other Universities such as North West University have not adopted policies establishing such a parliamentary structure. ${ }^{43}$

It is submitted that Higher Education institutions should strive to promote the recognition of student parliamentary structures and other related bodies to allow students to develop and mature their own democratic jurisprudence with the necessary policy guidance.

The creation of student parliamentary structures is also grounded in writings of Rousseau. He argued that the Sovereign, having no force other than the legislative power, acts only by means of the laws; and the laws being solely the authentic acts of the general will, the Sovereign cannot act save when the people is assembled. ${ }^{44}$ In this instance, the sovereign we refer to the SRC, and the people's assembly would be the sub structures, societies, and other committees that report to the SRC. The creation of parliamentary arrangements would then ensure that if a recall clause is being utilised, it is utilised in a transparent manner, and the decision has to be adopted by a collective representation of the student populace.

\section{Conclusion and Recommendations}

In his inaugural lecture, Mbao articulated that 'the law is used to limit, contain and control the use of state power, to safeguard our civil liberties and fundamental freedoms. At the same time, it is absolutely important to note that our freedoms can exist only within a constitutional framework anchored on constitutionalism and enforceable law administered by an independent judiciary and enacted by an independent parliament. ${ }^{45}$ This view was further affirmed in Pharmaceutical Manufacturers Association of South Africa and Another: In Re Ex Parte President of the Republic of South Africa and Others that under our new constitutional order the control of public power is always a constitutional matter. ${ }^{46}$

This paper has argued how the recall clause in the constitutions governing student structures in South African Higher Education is prima facie a deliberate product of democracy, public accountability and transparency. Caution should however be applied in the utilisation of the recall provisions. Institutions should strive to create a parliamentary student bodies in which all student structures that are legitimately affiliated to the SRC can debate and adopt such a motion to recall a student leader. The rationale behind this proposition is that once a deploying party successfully contests a particular SRC portfolio, such an office bearer is then elevated to become a caretaker of the whole student body and not just the political body that campaigned for him. It then requires that if the political body feels such an office bearer is no longer the fit and proper representative they anticipated he will become, objectively, the grounds of his recall should be able to sway the student parliament in support of the motion to have such a person recalled.

This paper concludes that in view of the democratic principles enshrined in the Constitution of the Republic of South Africa, any exercise to recall a student leader by a deploying structure without the support or adoption by the majority of members in a legitimate student parliamentary structure (or student mass meeting) does not espouse that values of transparency.

\footnotetext{
${ }^{41}$ White Paper, Ibid note 13, Principle 3.3.

${ }^{42}$ See University of Cape Town, https://www.uct.ac.za/apply/welcome/english/, University of South Africa, http://www.unisa.ac.za/ contents/management/src/docs/src-, University of Free State, constitution.pdf,http://www.ufs.ac.za/dl//userfiles/documents/00000/135_eng.pdf, Nelson Mandela Metropolitan University, http://src.nmmu.ac.za/News/Student-Parliament. (Accessed 2014-06-05).

${ }^{43}$ See North West University www.nwu.ac.za (Accessed 2014-06-05)

${ }^{44}$ Rousseau, J. J., \& Singh, E. B. N, Ibid note 32.

45 Mbao, M., Ibid note 31, pp 17.

462000 (2) SA 674 (CC) at para 33-45.
} 


\section{References}

Journals

Bovens, M. (2005). Public accountability. The Oxford handbook of public management.

Mbao, M. L. M. (2010). Constitutionalism and the rule of law in the third millennium. North-West University

Reddy, T. (2004). Higher education and social transformation: South Africa case study. Council For Higher Education.

Rothchild, J. (2007). Introduction to Athenian Democracy of the Fifth and Fourth Centuries BCE. Wayne State University Law School Research Paper.

Books

Vile, M. J. C. (1967). Constitutionalism and the Separation of Powers, Oxford: Clarendon Press.

Legislation

Constitution of the Republic of South Africa Act 108 of 1996.

Nelson Mandela Metropolitan University (NMMU) SRC Constitution, (2006) revised 2010.

Statute of the North West University, 2005.

Technikons Act No. 125 of 1993.

Tertiary Education Act No. 66 of 1988.,

The University of Kwazulu-Natal SRC Constitution (2006).

Universities Act No.61 of 1955

University of South Africa (UNISA) SRC Constitution, (2006) revised 2013.

Walter Sisulu University SRC Constitution, (2012).

White Paper on Higher Education, General Notice 1196 of 1997

\section{Web Sources}

Nelson Mandela Metropolitan University: Available http://src.nmmu.ac.za/News/Student-Parliament (2014-06-05).

North-West University: Available www.nwu.ac.za (2014-06-05).

University of Cape Town; Available https://www.uct.ac.za/apply/welcome/english/ (2014-06-05).

University of Free State: Available: constitution.pdf,http://www.ufs.ac.za/dl/userfiles/documents/00000/135_eng.pdf (2014-06-05).

University of South Africa: Available http://www.unisa.ac.za/contents/management/src/docs/src- (2014-06-05).

Cases

Baloro v University of Bophuthatswana 1995 (4) SA 197.

Klein v Dainfern College and Another 2006 (3) SA 73 (T).

Pharmaceutical Manufacturers Association of South Africa and Another: In Re Ex Parte President of the Republic of South Africa and Others 2000 (2) SA 674 (CC). 